\title{
Interactive comment on "Marine Rapid Environmental Assessment in the Gulf of Taranto: a multiscale approach" by N. Pinardi et al.
}

N. Pinardi et al.

n.pinardi@sincem.unibo.it

Received and published: 31 October 2016

The answers to both the reviewers is in a unique file added here as a supplement pdf

Please also note the supplement to this comment:

http://www.nat-hazards-earth-syst-sci-discuss.net/nhess-2016-179/nhess-2016-179-

AC1-supplement.pdf

Interactive comment on Nat. Hazards Earth Syst. Sci. Discuss., doi:10.5194/nhess-2016-179, 2016.

Printer-friendly version

Discussion paper 